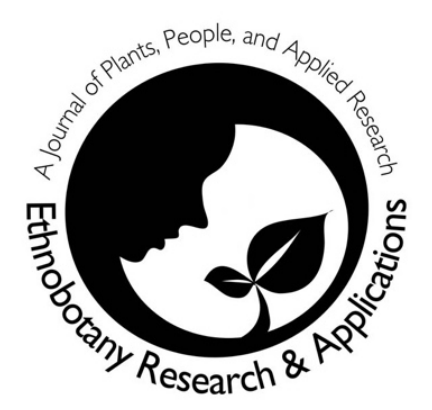

\section{Ethnobotany of medicinal plants with antimalarial potential in Northern Nigeria}

\author{
Abdulrahman Mahmoud Dogara, Isah Labaran and \\ Abdulkadir Yunusa
}

\section{Research}

\begin{abstract}
Background: Traditional medicinal plants with potentials have contributed significantly in the history and evolution of modern health care system. Plants with medicinal value remain the only way forward as they are gaining more acceptability and recognition all over the world. Resistance of the malarial parasite all over the world has initiated the need for the exploration of plant parts for the invention of promising antimalarial drugs. In order to achieve this, a prior knowledge of the medicinal plants is needed from the traditional medical practitioners and any other person utilizing plants for medicinal purposes.
\end{abstract}

Methods: The study was carried out through the administration of open-ended questionnaires to the age group of 30 and above. No prior appointment was made to the informants. A total of 100 informants were interviewed.

Results: This study revealed 21species of medicinal plants. Malvaceae family have the highest abundance. Only plants with 0.5 relative frequency of citation and above were also listed. Leaves accounted for $35 \%$ of the most utilized parts, while decoction and oral were the most utilized methods of preparation and utilization at $44 \%$ and $60 \%$ respectively. Scientific validation of the documented medicinal plants is paramount in order to confirm, identify and isolate the compound responsible for antimalarial activity.

Conclusion: Findings from this study will help in the production of new anti-malaria drugs, development of herbal product for malaria treatments and conservation of the medicinal plants with malarial therapeutic value to avoid future oversampling. The study hence recommends further studies on the in vitro and in vivo studies of the plant parts.
Keywords: Traditional Medicinal Knowledge, Medicinal Plants, Northern Nigeria

\section{Correspondence}

Abdulrahman Mahmoud Dogara *1, Isah Labaran and Abdulkadir Yunusa ${ }^{3}$

${ }^{1}$ Department of Biological Sciences, Faculty of Science, Kaduna State University, P.M.B 2339, Kaduna state, Nigeria

2Department of Sciences Laboratory Technology, School of Science, Federal polytechnic Mubi, Adamawa state, Nigeria

${ }^{3}$ Department of Basic and Applied Science, Federal Polytechnic Mubi, Adamawa state, Nigeria

"Corresponding Author:

abdulrahmanjj@kasu.edu.ng /

isalkogobir@gmail.com

\section{Ethnobotany Research \& Applications}

19:32 (2020)

\section{Background}

All over the world, malaria has been considered as one of dangerous diseases of public health. It has been estimated that more than 3.2 billion people are at risk of being infected by malaria parasite (Pappas et al. 2008, Ruiz et al. 2011, Ramírez and Blair 2017). Malaria parasite has been the greatest cause of mortality and morbidity in the world than any other infectious diseases (Tor-Anyiin et al. 2003). Plasmodium ovale, Plasmodium falciparum, Plasmodium vivax and Plasmodium malariae have been reported as the causal organisms of malaria (Tor-Anyiin, Sha'ato et al. 2003). Malaria parasites infect more than three hundred million people all over the world annually (Ramírez and Blair 2017). Ramírez \& Blair (2017) reported in Latin America 
approximately four hundred-thousand people died annually from the diagnosis of the malaria parasite. Africa was documented to have more than one hundred-million infected with malaria disease annually (Odugbemi et al. 2007). After HIV, malaria is the second most-deadly disease in Africa (Nashriyah et al. 2012, Olorunnisola et al. 2013). Survey of the infectious diseases carried out revealed that more than $90 \%$ of the reported cases of malaria are in African countries (O'Meara et al. 2010). It has been noted that in every 10 of the reported cases all over the world, 9 are from African countries (Odugbemi et al. 2007). The parasite infect mostly pregnant women and children faces high mortality from category of populace (Greenwood and Mutabingwa 2002). The said diseases have negative effect on the economy and the development of the African countries (Odugbemi et al. 2007). Malaria disease has been considered to be endemic in Nigeria (Odugbemi et al. 2007, Ayoola et al. 2008). Odugbemi et al. (2007) reported that one in every ten death of pregnant woman is as a result of been infected by one of the malaria parasites and this has caused Nigerian government to spend more than one billion annually for the treatment of malaria. Three hundred thousand deaths are reported to be caused by malaria parasite in Nigeria annually (Olorunnisola et al. 2013). Reported cases of malaria parasites in northern part of Nigeria is seasonal while it occurs throughout the year in southern part of the country (Omosun et al. 2013, Awang et al. 2018). Resistance of Malaria parasites to the drugs has become the major challenge in control of malaria in the world (Dike et al. 2012, Olorunnisola et al. 2013, Omosun et al. 2013). Increase in the rapid spread of resisting malaria parasites coupled with adulteration of antimalaria drugs; have made the control and the treatment difficult as noted by (Olorunnisola et al. 2013). Plasmodium vivax and Plasmodium falciparium have been reported resistant to antimalarial drugs which are currently in use (Omosun et al. 2013). As a result of global warming, malaria parasite is becoming addict or resistant to the current antimalaria in usage (Dike et al. 2012). Though, communities living in an endemic area of malaria parasites have already been utilizing remedies from plants (Olorunnisola et al. 2013). Traditional medicinal plants where for long established in African countries to be effective in curing malaria (Dike et al. 2012). According to Dike et al. (2012), ethnobotanical study is the major foundation for the development and selection of medicinal plants for therapeutic purpose. Many developing countries utilize plants as the major sources of therapeutic agent for the treatment of various ailment (Abdulrahman et al. 2018). As reported by the World Health Organization (WHO) in 2001 , more than $70 \%$ of the world population relied on traditional herbal medicine and Nigeria is inclusive (Abdulrahman et al. 2018). From time immemorial, diverse number of diseases has been treated with traditional medicinal knowledge (Dike et al. 2012), and presently, products from plant sources have been the major concern of health managers (Olorunnisola et al. 2013, Abdulrahman et al. 2018). The success of traditional medicinal utilization is a result of increased awareness of the potentials of the remedies from medicinal plants to cure diverse ailment as clearly stated by (Awang et al. 2018, Mahmoud et al. 2019). It has been established that the abundant plant diversity of Nigeria will provide a promising novel compound of antimalaria agent if explored. Therefore, usage of quantitative and qualitative data remains the only means to gather information from the unutilized Nigerian plants for the advent of new compounds of antimalarial drugs. Though, quite a number of studies have been carried out in the southern part of the country, but not much similar studies have been embarked upon in the northern area. This study, therefore aimed at documenting the important medicinal plants with antimalarial potential in Mubi, Adamawa State of Northeast Nigeria through qualitative and quantitative ethnobotanical data.

\section{Materials and Methods Study Area}

Mubi is a town located in Northern Senatorial District of Adamawa State, Northeast, Nigeria. It lies on latitude $10^{\circ} 16^{\prime} \mathrm{N}$ and longitude $13^{\circ} 16^{\prime} \mathrm{E}$ (Figure 1). The major inhabitant towns are Fulani, Hausa, Mundang (Godo-godo), Gude Nzanyi, Fali, Marghi and Higgi. The inhabitants were mainly fishermen, farmers and businesspeople. The areas were known to be malaria endemic region because of the nature of the weather. The climatic condition is characterized by two distinct weather rainy and dry seasons.

\section{Administration of Questionnaire}

The data was collected from the informants (traditional medical practitioners, birth attendants, herbalist and rural dwellers) using semi structured questionnaire. The questionnaire was validated by three professional botanists and pre-tested before employed in the study. Informants were chosen without any bias to gender (Table 1). Only informants who attained the age of 30 and above where interviewed. Random sampling was employed. In all, a total of 100 informants were interviewed, and no prior appointment was made with the informants. Informants were however informed on the need why the studies should be carried out before the advent of the interview. The research was carried out between February and December 2018. 


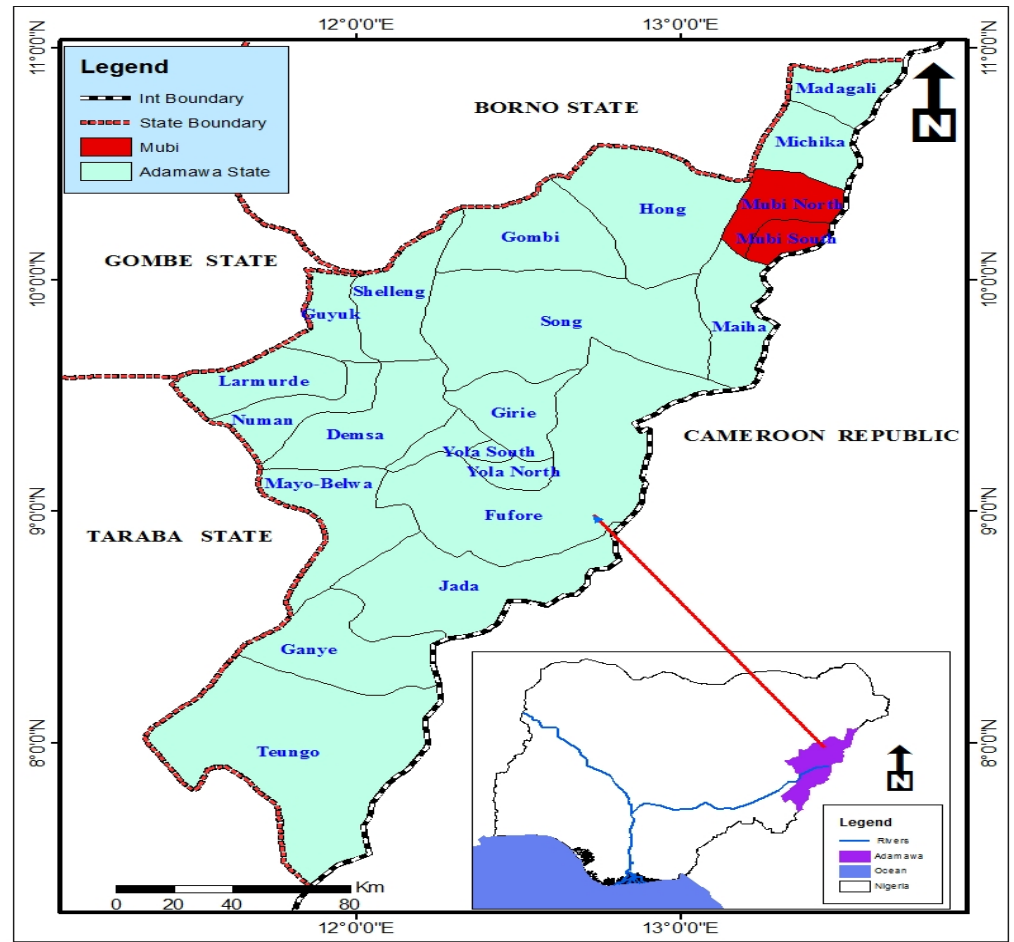

Figure 1. Geographic location of Mubi, Adamawa state Northern Nigeria where the survey was carried out

Table 1. Some questions employed during the interview to the populace about the medicinal plants used for the treatments of Malaria parasites

\begin{tabular}{l}
\hline \multicolumn{1}{c}{ Questionnaire } \\
\hline Gender \\
Age \\
Education \\
Occupation \\
If traditional herbalist for how long? \\
Name of the Plant you know for the treatment of \\
malaria \\
How did you diagnose patient with malaria \\
Diseases cured with the plant apart from \\
malaria? \\
Other uses of the plant \\
Is the plant wild or cultivated \\
What part of the plant use? \\
Method of preparation \\
Method of administration \\
Is any part of the plant toxic? \\
How did you distinguish medicinal plants? \\
What type of medication you prepared? \\
Do you think traditional knowledge should be in \\
cooperated to hospital?
\end{tabular}

\section{Herbarium Deposition and Taxonomic} Identification

Herbarium specimens were prepared for the collected samples of the medicinal plants from home gardens and natural habitats. The collected plants were identified in the field by a Botanist in the
Agricultural department, School of Science at the Federal Polytechnic Mubi, Adamawa state of Nigeria and finally deposited at the school herbarium.

\section{Data Analysis}

A simple descriptive analysis was employed for the obtained ethnobotanical data to determine the percentage and frequencies, and thereafter tabulated based on the following information:

I. Socio demographic information of the informants

II. Taxonomic information, mode of preparation, mode of administration, parts of the plant utilized and growth form.

III. Informants perspective on the usage of traditional knowledge for the treatment of malaria

IV. Quantitative data was also computed based on the following indices:

(a) Relative Frequency of Citation (RFC): The above parameter was used to determine the plant relative importance within the community. Whereby, RFC = $\mathrm{Fc} / \mathrm{N}, \mathrm{Fc}$ is the number of informants who cited the particular plant species while $\mathrm{N}$ is the total number of informants interviewed(Kankara, Ibrahim et al. 2015, Abdulrahman, Ali et al. 2018). 


\section{Results}

Demographic information of the Informants

The study interviewed a total of 100 informants from Mubi, Adamawa state Northern part of Nigeria, and among these informants, $81 \%$ were male and the remaining $19 \%$ were female (Figure 2). In general, informants with average age of 61-70 where mostly interviewed, accounting for $32 \%$ of the total number. This was closely followed by those whose age were between $51-60(26 \%)$ and the least category age of the informants interviewed was 41-50 with $3 \%$ (Table 2). Majority of the informants interviewed (44\%) did not attend western education , while $34 \%$ attended basic education (primary school). 13\% attended post basic education (secondary school) while only $19 \%$ of the informants had tertiary education (Table 2). Of all the informants interviewed, $28 \%$ were traditional herbalist, $15 \%$ traditional birth attendants, $25 \%$ were farmers and $32 \%$ were either businessmen, housewives, religion teachers or any other occupation (Table 2).

Table 2. Demographic information of the informants in Mubi Northern Nigeria

\begin{tabular}{lll}
\hline Gender & Frequency & Percentage \% \\
\hline Male & 81 & 81 \\
Female & 19 & 19 \\
Age & & \\
$30-40$ & 20 & 20 \\
$41-50$ & 3 & 3 \\
$51-60$ & 26 & 26 \\
$61-70$ & 32 & 32 \\
$71>$ & 19 & 19 \\
Education & & \\
None & 44 & 44 \\
Basic & 34 & 34 \\
Post Basic & 13 & 13 \\
Tertiary & 19 & 19 \\
Occupation & & \\
Traditional & 28 & 28 \\
Herbalist & & \\
Birth Attendants & 15 & 15 \\
Farmer & 25 & 25 \\
Others & 32 & 32 \\
\hline
\end{tabular}

Detail Information of Plants and Taxonomic Diversity

A total of twenty-one species of medicinal plants from 18 families were reported to be used by Hausa ethnic group in the Northern part of Nigeria for the treatment of malaria. Detailed information of these plants is presented in (Table 3). It provides the comprehensive information on the family of the plant, botanical name of the plants, English and Hausa names of the plants, domestication status of the plants, form of growth, mode of preparation and mode of administration to the patient with malaria. Malvaceae was reported to be more abundant, followed by Poaceae. Only plants species with 0.4 RFC was reported in the following study (Table 3).

Dosage, Parts of the Plants Utilized, Mode of Preparation and Administration

No amount of recommended dosage was reported by the informants, to be taken for the treatments of malaria in the study area, but some of the traditional herbalist and traditional birth attendants believed that the factors considered for the dosage of patient with malaria diseases are severity, age and gender. The leaves were the most utilized plant part (35\%) for the treatment of malaria, followed by the roots $-34 \%$, whole plants $-16 \%$ and bark $15 \%$ (Figure 3 ). For the methods for the preparation, decoction constituted about $44 \%$, infusion $19 \%$, direct application $13 \%$ and powdered and poultice $12 \%$ respectively (Figure 4 ).

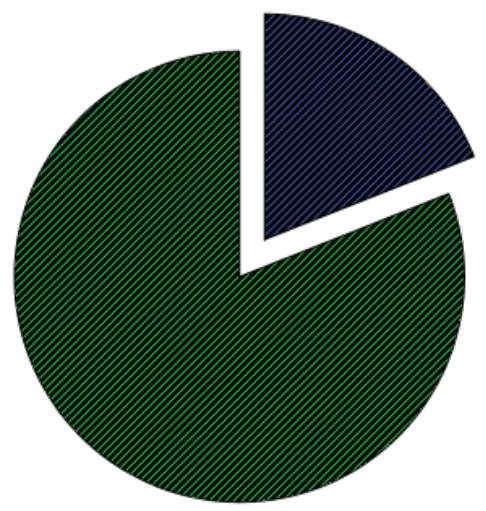

Figure 2. Demographic gender of the Informant from Mubi Northern Nigeria

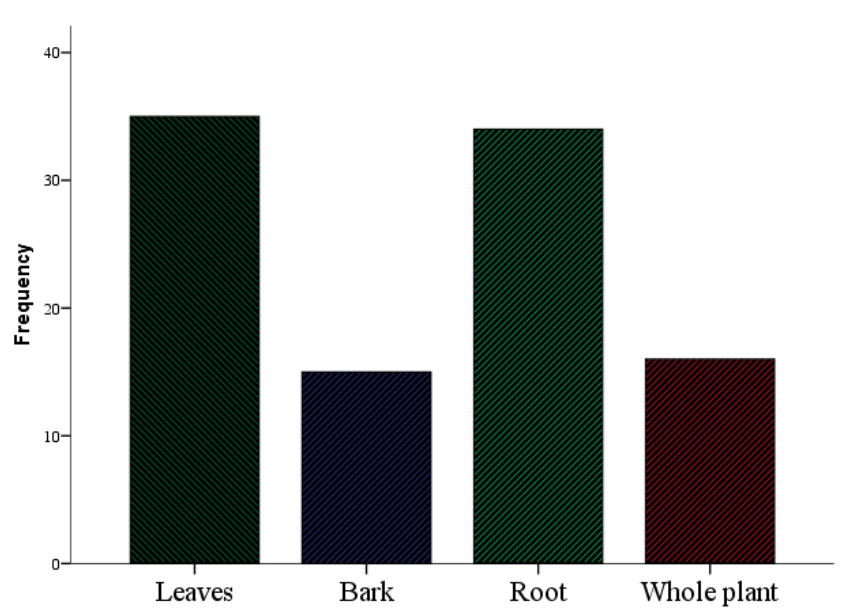

Figure 3 Plant parts utilized by the Hausa ethnic group of Mubi Northern Nigeria in the traditional treatment of malaria 


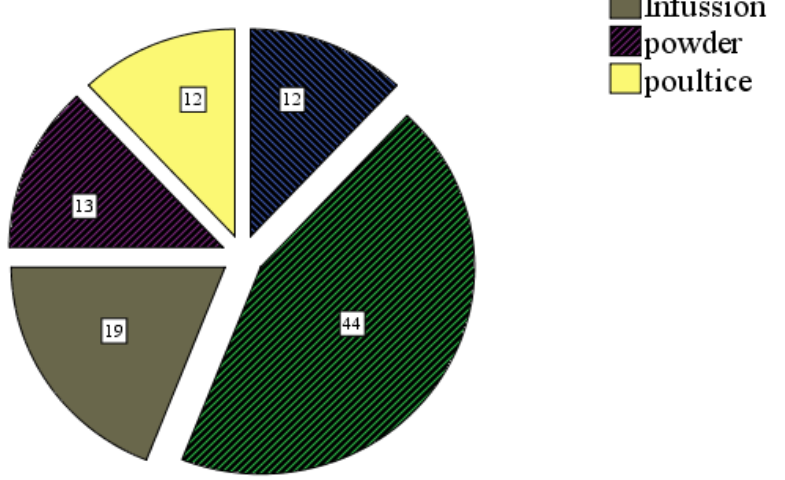

Figure 4. Methods of herbal preparation

Sixty percent $(60 \%)$ of the informants reported oral mode of administration as the most effective, dermal (the direct application of prepared medicine on the body - either whole body, face, stomach or any order place in the body) constituted $21 \%$, while the remaining $19 \%$ reported the usage of oral and dermal at the same time (Figure 5).

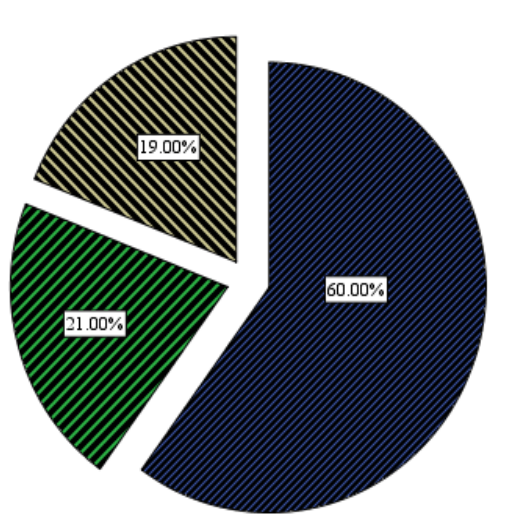

WOral
WDermal
NBoth

Figure 5. Method of Administration of Traditional Medicine from the Informant of Mubi Northern Nigeria

\section{Toxicity}

The informants noted that the species listed in this study have not been previously reported to be toxic, to the best of their knowledge. However, information gathered from their parents is that medicinal plants could only be toxic as a result of misidentification of plant species

\section{Discussion}

Throughout the history of man, every ethnic group practically have traditional medicinal system, how man has been utilizing plants around his community for the treatment of wide variety of ailments for himself and his domesticated animal. Some of the plants were also utilized for religion purpose, depending on the culture and believe of the community. The World Health Organization (WHO) described traditional medicinal system as the cheapest means of attaining health status of the largest group of the world population. Nashriyah et al. (2012) also described traditional medicine as the summation of practice of trial and error of past generation for the treatment of diseases and improvement of health status. Similarly, Abdulrahman et al. (2018) described traditional medicine as the in cooperation of culture, beliefs, toward the application of traditional medicinal plants in the health practice. Awang et al. (2012) defined traditional medicine as the summation of total practice, knowledge used for the diagnosis, elimination and prevention of physical or nonphysical illness based on the observation and practical experiences of the past generations. Observations from the present study revealed that most of the informants were men, and this might be due to the religious belief of the informants, who noted that women are not allowed to move freely within the community.

This study agreed with the findings of Olorunnisola et al. (2013) who reported that all the 250 respondents interviewed in the survey of ethnobotanical medicinal plants used for the diagnosis of malarial in Ogbomoso, Southwest Nigeria are males. Also, the finding of the study agrees with Dike et al. (2012), who also reported only $24 \%$ of the respondents' interview to be housewives in the survey of medicinal plants with potential of antimalaria treatment in the south western part of Nigeria. Furthermore, this study has documented 21 species of plants from 18 families and only plants with $\geq 0.4$ relative frequency of citations were reported. The informants reported no specific dosage for the administration of traditional medicinal plants for the treatments of malaria. Similarly, no dosage has previously been reported by authors of similar studies (Tor-Anyiin et al. 2003, Dik et al. 2012, Olorunnisola, Adetutu et al. 2013, Abdulrahman et al. 2018).

Lack of proper dosage of traditional medicinal plants pose a serious challenge to the consumption of traditional medicinal plants. Despite reporting traditional medicinal plants to be nontoxic but still if taken in excess it can pose a serious challenge to health (Abdulrahman et al. 2018). For the treatment of malaria, leaves were found as the most utilized parts. This agrees with the previous ethnobotanical studies carried out in Nigeria and other parts of the word (Tor-Anyiin et al. 2003, Dike et al. 2012, Adetutu et al. 2013, Abdulrahman et al. 2018). 
Table 3. Taxonomic Diversity of Medicinal Plants used by Hausa Ethnic group in Northern Nigeria

\begin{tabular}{|c|c|c|c|c|c|c|c|c|c|}
\hline Family name & Botanical name & English Name & $\begin{array}{l}\text { Vernacular } \\
\text { name }\end{array}$ & $\begin{array}{l}\text { Parts of the plant } \\
\text { used }\end{array}$ & $\begin{array}{l}\text { Method of } \\
\text { Preparation }\end{array}$ & $\begin{array}{l}\text { Domestication } \\
\text { status }\end{array}$ & Growth form & RFC & $\begin{array}{l}\text { Voucher } \\
\text { number }\end{array}$ \\
\hline Anacardiaceae & Magnifera indica L. & Mango tree & Mongoro & $\begin{array}{l}\text { Leaves, Fruits, } \\
\text { Immature stem }\end{array}$ & Decoction & W/ C & Tree & 0.93 & IL 341 \\
\hline Aizoaceae & $\begin{array}{l}\text { Trianthema portulacastrum } \\
\text { L. }\end{array}$ & $\begin{array}{l}\text { Desert } \\
\text { horsepurslane }\end{array}$ & Baushe & Leaves & $\begin{array}{l}\text { Maceration and } \\
\text { Decoction }\end{array}$ & W & Herb & 0.47 & AK 104 \\
\hline Apocynaceae & Leptadenia hastata Vatke & Tears & Yadiya & Leaves, Fruits & $\begin{array}{l}\text { Direct and } \\
\text { Decoction }\end{array}$ & W & Herbs & 0.73 & IL 356 \\
\hline Acanthaceae & Barleria prionitis $\mathrm{L}$. & Porcupine flower & Sinkinmini & Leaves & Decoction & W & Herb & 0.86 & ABD 244 \\
\hline Arecaceae & $\begin{array}{l}\text { Calamus guruba Buch.- } \\
\text { Ham. ex Mart. }\end{array}$ & Assamese & Guruba & Fruits & $\begin{array}{l}\text { Decoction and } \\
\text { Infusion }\end{array}$ & $\mathrm{W} / \mathrm{C}$ & Tree & 0.73 & ABD 245 \\
\hline Apiaceae & Daucus carota L. & Carot & Karoti & Root & Decoction & C & Herb & 0.56 & ABD 248 \\
\hline Amaranthaceae & Spinacia oleracea L. & Amaranthus & Zakin baza & Leaves, Flower & $\begin{array}{l}\text { Direct and } \\
\text { Decoction }\end{array}$ & W & Herbs & 0.87 & AK 108 \\
\hline Asteraceae & $\begin{array}{l}\text { Acanthospermum hispidum } \\
\text { DC. }\end{array}$ & Hispid starbur & Kashin yawu & Whole plant & $\begin{array}{l}\text { Decoction and } \\
\text { Infusion }\end{array}$ & W & Herb & 0.53 & ABD199 \\
\hline Combretaceae & $\begin{array}{l}\text { Guiera senegalensis J.G. } \\
\text { Gmel. }\end{array}$ & Guiera & Sabara & Back, Roots & Direct & W & Shrub & 0.63 & IL 333 \\
\hline Caricaceae & Carica papaya L. & Pawpaw & Gwanda & Leaves & $\begin{array}{l}\text { Infusion and } \\
\text { Decoction }\end{array}$ & $\mathrm{W} / \mathrm{C}$ & Tree & 0.87 & IL 332 \\
\hline Euphorbiaceae & Euphorbia unispina N.E. Br & Spurge & Tinya & Whole plant & $\begin{array}{l}\text { Direct and } \\
\text { Decoction }\end{array}$ & W & Tree & 0.73 & ABD 261 \\
\hline Fabaceae & Pterocarpus erinaceus Poir & Africana teak & Madubiya & Bark, Roots & $\begin{array}{l}\text { Direct and } \\
\text { Decoction }\end{array}$ & W & Tree & 0.73 & AK 109 \\
\hline Meliaceae & $\begin{array}{l}\text { Azadirachta indica A. } \\
\text { Juss. }\end{array}$ & Neem tree & $\begin{array}{l}\text { Delbejiya / } \\
\text { Dogon yaro }\end{array}$ & Back, Leaves & Decoction & $\mathrm{W} / \mathrm{C}$ & Tree & 0.93 & AK 111 \\
\hline Myrtaceae & Psidium guajava L. & Guava & Gwaiva & $\begin{array}{l}\text { Leaves, Immature } \\
\text { stem }\end{array}$ & $\begin{array}{l}\text { Direct and } \\
\text { Decoction }\end{array}$ & W/ C & Tree & 0.97 & ABD 249 \\
\hline Malvaceae & Hibiscus sabdariffa DC. & Roselle & Soboroto & Whole plant & $\begin{array}{l}\text { Decoction and } \\
\text { Infusion }\end{array}$ & W & Herb & 0.86 & ABD 230 \\
\hline Malvaceae & Gossypium barbadense L. & Cotton & Auduga & Leaves, Bark, Root & Decoction & $\mathrm{W} / \mathrm{C}$ & Tree & 0.86 & ABD 255 \\
\hline Malvaceae & $\begin{array}{l}\text { Abelmoschus esculentus } \\
\text { (L.) Moench. }\end{array}$ & Okro & Kubewa & Leaves, Bark & $\begin{array}{l}\text { Decoction and } \\
\text { infusion }\end{array}$ & $\mathrm{W} / \mathrm{C}$ & Herb & 0.56 & AK 112 \\
\hline Poaceae & $\begin{array}{l}\text { Bambusa arundinacea } \\
\text { (Retz.) Willd. }\end{array}$ & Common bambo & Gora & Whole plant & Decoction & W & Tree & 0.56 & AK 113 \\
\hline Poaceae & $\begin{array}{l}\text { Cymbopogon citratus (DC.) } \\
\text { Stapf. }\end{array}$ & Lemon grass & Tsauri & Whole plant & Infusion & W & Herbs & 0.86 & AK 114 \\
\hline Rhamnaceae & Ziziphus mauritiana Lam. & Indian plum & Magarya & $\begin{array}{l}\text { Leaves, Bark and } \\
\text { Seeds }\end{array}$ & Decoction & W & Tree & 0.73 & ABD 252 \\
\hline Rutaceae & $\begin{array}{l}\text { Citrus } \mathrm{x} \text { sinensis (L.) } \\
\text { Osbeck. }\end{array}$ & Orange & Lemu & Leaves & $\begin{array}{l}\text { Direct, Infusion } \\
\text { and Decoction }\end{array}$ & $\mathrm{W} / \mathrm{C}$ & Tree & 0.76 & ABD 251 \\
\hline
\end{tabular}

Relative Frequency Citation (RFC), Wild (W) and Cultivated (C) 
Frequent utilization of the leaves in the present and previous study carried out was due to the scientific evidence of secondary metabolites production in the leaves and are sole responsible for antimalarial action as noted by (Abdulrahman et al. 2018). Despite the frequent utilization of leaves, it has a serious effect on global warming by the reduction in the uptake of Carbon-Dioxide and reduction in the production of oxygen (Awang et al. 2018, Mahmoud et al. 2019). Decoction using water as a diluent was reported as the most utilized method, and this is in line with previous studies (Awang et al. 2018, Mahmoud et al. 2019). The reasons why decoction is the most utilized method is as a result of the ability of hot water to extract almost all the compounds in the plants parts. Oral administration is also the most frequent form of utilization in the present study. This study also observed that most of the medicinal plants used for the treatment of malaria are utilized fresh and dried. The informants also reported that the combination of more than one plants were found to be more effective in the treatment of malaria. They further noted nontoxicity of traditional medicinal plants used for the treatment of malaria.

\section{Conclusions}

This study recommends validation of the listed plants for antimalaria effectiveness and the claim of the traditional herbalist that none of the medicinal plants used for the treatment of malaria is toxic. Our paper has provided an avenue for the possible exploration of the phytochemicals in the mentioned medicinal plants above to overcome the challenge of drug resistance of malarial parasite. It is hoped that exploration of phytochemical compounds from the plants parts will save our biodiversity from future extinction, resulting from over-collection of plant parts by the traditional herbalists.

\section{Declarations}

List of abbreviations: Not applicable

Ethics approval and consent to participate: The ethical issue in relation to this study was orally explained to the informants and the needs for the study to be conducted in the community. Prior to the interviewed session, informants gave their oral consent.

Consent for publication: Not applicable.

Competing interests: The authors do not have any competing interests.

Funding: The authors declare that there is no involvement of any organization or entity with financial or non-financial interest in the subject matter.

Authors contributions: All authors contributed equally in this study.

\section{Acknowledgements}

The authors acknowledge the support of traditional rulers, religious leaders, traditional medical practitioners, traditional birth attendants and all the informants who participated in the study for sharing their valuable time and wealth of knowledge with us. The research did not receive any specific grant from funding agencies in the public, commercial or not for profit sector.

\section{Literature Cited}

Abdulrahman MD, Ali AM, Fatihah H, Khandaker MM, Mat N. 2018. Traditional medicinal knowledge of Malays in Terengganu, Peninsular Malaysia. Malayan Nature Journal 70: 349-364.

Awang NA, Ali AM, Abdulrahman MD, Mat N. 2018. Edible Bitter Mushroom from Besut, Malaysia. Journal of Agrobiotechnology 9:70-79.

Ayoola, G., Coker, H., Adesegun, S., Adepoju-Bello, A., Obaweya, K., Ezennia, E. C., \& Atangbayila, T. (2008). Phytochemical screening and antioxidant activities of some selected medicinal plants used for malaria therapy in Southwestern Nigeria. Tropical Journal of Pharmaceutical Research, 7(3):10191024

Dike IP, Obembe OO, Adebiyi FE. 2012. Ethnobotanical survey for potential anti-malarial plants in south-western Nigeria. Journal of Ethnopharmacology 144:618-626.

Greenwood B, Mutabingwa T. 2002. Malaria in 2002, Nature Publishing Group.

Kankara SS, Ibrahim M H, Mustafa M, Go R. 2015. Ethnobotanical survey of medicinal plants used for traditional maternal healthcare in Katsina state, Nigeria. South African journal of botany 97:165-175.

Mahmoud AD, Ali AM, Khandaker MM, Fatihah HNN, Awang NA, Mat N. 2019. Discrimination of Syzygium polyanthum Cultivars (Wight) Walp Based on Essential oil Composition. Journal of Agrobiotechnology 101-116.

Nashriyah M, Salmah T, NurAtiqah M, Indah OSN, MuhamadAzhar A, Munirah S, Manaf A A. 2012. Ethnobotany and distribution of Dioscorea hispida Dennst. (Dioscoreaceae) in Besut, Marang and Setiu Districts of Terengganu, Peninsular Malaysia. International Journal of Agricultural and Biosystems Engineering 6:1151-1154.

O'Meara W P, Mangeni J N, Steketee R, Greenwood B. 2010. Changes in the burden of malaria in subSaharan Africa. The Lancet infectious diseases 10:545-555.

Odugbemi T O, Akinsulire O R, Aibinu I E, Fabeku P O. 2007. Medicinal plants useful for malaria therapy in Okeigbo, Ondo State, Southwest Nigeria. African 
Journal of Traditional, Complementary and Alternative Medicines 4:191-198

Olorunnisola O, Adetutu A, Balogun E, Afolayan A. 2013. Ethnobotanical survey of medicinal plants used in the treatment of malarial in Ogbomoso, Southwest Nigeria. Journal of Ethnopharmacology 150:71-78.

Omosun, G., Okoro, I., Ekundayo, E., Ojimelukwe, P., \& Ibe, O. (2013). Ethnobotanical study of medicinal plants useful for malaria therapy in eight local government areas of Abia State, Southeast Nigeria. Advancement in Medicinal Plant Research 1(2):39-44

Pappas G, Papadimitriou P, Siozopoulou V, Christou L, Akritidis N. 2008. The globalization of leptospirosis: worldwide incidence trends. International journal of infectious diseases 12: 351357.

Ramírez O, Blair S. 2017. Ethnobotany of medicinal plants used to treat malaria by traditional healers from ten indigenous Colombian communities located in Waupes Medio Biodiversity International Journal 1:151-167.

Ruiz L, Ruiz L, Maco M, Cobos M, GutierrezChoquevilca AL, Roumy V. 2011. Plants used by native Amazonian groups from the Nanay River (Peru) for the treatment of malaria. Journal of Ethnopharmacology 133:917-921.

Tor-Anyiin T, Sha'ato R, Oluma H. 2003. Ethnobotanical survey of anti-malarial medicinal plants amongst the Tiv people of Nigeria. Journal of Herbs, Spices \& Medicinal Plants 10:61-74. 